\title{
Pengaruh Prosedur Pemberian Kredit Terhadap Peningkatan Jumlah Nasabah
}

\author{
Muhammad Anas, SE, MM * \\ STIE Ichsan Pohuwato \\ Email : muh.annas74@yahoo.com
}

\begin{abstract}
Basically, credit is something mostly needed by the society that can supporting and running well the commerce activities, whether in goods productions, service and also improving or fulfilling the need of society consumption. The aim of this research is to analysis the provide credit facility, such as character, capacity, Capital, and the condition of economy towards some of bank customers of BRI Branch at Marisa in Pohuwato restrict. In this research it is used questionnaire that distributing towards 40 respondents in order to get information about the problems which being related to the variables observed. The analysis instrument used is multiple regressions. The result of this research showed that the research variable whether in a partial or simultaneous regression proved having positive influence and significantly towards improvement of BRI bank customers in Marisa at Pohuwato District.
\end{abstract}

Keywords : Credit Given Procedure, The Improvement Custemers

\section{PENDAHULUAN}

Peranan perbankan sangat mempengaruhi kegiatan ekonomi suatu negara. Bank dapat dikatakan sebagai darahnya perekonomian suatu negara. Oleh karena itu kemajuan suatu bank disuatu negara dapat pula dijadikan ukuran kemajuan negara yang bersangkutan. Semakin maju suatu negara, maka semakin besar peranan perbankan dalam mengendalikan negara tersebut. Artinya keberadaan dunia perbankan semakin dibutuhkan pemerintah dan masyarakat.

Banyak kebutuhan masyarakat yang terpenuhi dengan adanya usaha bank, baik dalam bentuk tabungan, deposito, sampai penggunaan kartu kredit. Bank itu sendiri diatur dalam Undang-Undang No. 10 Tahun 1998 tentang Perbankan, yang dalam peraturan tersebut memberikan pengertian tentang bank. Bank adalah badan usaha yang menghimpun dana dari masyarakat dalam bentuk simpanan dan menyalurkannya kepada masyarakat dalam bentuk kredit dan/atau bentuk-bentuk lainnya dalam rangka meningkatkan taraf hidup rakyat banyak. 
Tujuan pemberian jasa-jasa bank ini adalah untuk mendukung dan memperlancar kedua kegiatan utamanya, yaitu kegiatan menghimpun dan menyalurkan dana. Kelengkapan jasa bank yang diberikan sangat tergantung dari kemampuan bank tersebut, baik dari segi modal, perlengkapan fasilitas sampai kepada karyawan yang mengoperasikannya. Semakin lengkap tentunya semakin banyak pula modal yang dibutuhkan untuk melengkapi peralatan dan personilnya agar supaya kegiatan perbankan dapat memberikan keuntungan atau profit.

Dari uraian di atas, maka persaingan dalam dunia perbankan dikatakan cukup ketat ini dibuktikan dengan banyaknya bank yang menawarkan jasa-jasa selain menabung, seperti asuransi, debit dan kredit dalam satu kartu. Oleh karena itu untuk mempertahankan kelangsungan hidupnya, maka pihak perbankan harus mampu mengelola usahanya dalam rangka mempertahankan dan menarik calon nasabah baru sehingga perusahaan perbankan harus bekerja secara optimal. Namun, perlu diingat bahwacalon nasabah yang ingin melakukan pinjaman harus diseleksi secara ketat demi mengurangi terjadinya kredit macet.

Kredit macet terjadi karena tidak ketatnya seleksi yang dilakukan oleh pihak perusahaan perbankan dalam menyalurkan dana atau modal kepada nasabah sehingga ada beberapa nasabah yang lolos dalam pemberian dana sementara nasabah tersebut tidak mampu untuk mengembalikan dana yang telah dipinjamkan oleh pihak perbankan kepadanya.

Setiap perbankan yang menyalurkan kreditnya tentu terdapat suatu kebijakan yang menjadi landasan atau ketentuan untuk menentukan debitur mana yang layak dalam memperoleh kredit, begitupun halnya dengan Bank BRI, yang telah menerapkan prinsip 5C seperti ketentuan dari Bank Indonesia. Walaupun kebijakan pemberian kredit telah diterapkan, namun kredit bermasalah tetap saja muncul, dimana akan mengganggu kesehatan bank itu sendiri. Ada beberapa faktor yang menyebabkan kredit bermasalah, baik itu dari faktor internal maupun dari faktor eksternal.

Salah satu upaya yang dilakukan dalam menghindari terjadinya indikasi kredit bermasalah, yaitu dengan adanya kebijakan pemberian kredit yang terdiri dari prinsip " $5 \mathrm{C}$ " (the five cof credit) yaitu character, capacity, capital, collateral, dan condition, dan bukan hanya itu saja dari pihak analis kredit sebaiknya memiliki kemampauan dalam memahami prinsip 5C agar diperoleh debitur yang memiliki kemampuan dalam mengembalikan pinjaman atau 
Pengaruh Prosedur Pemberian

Volume. 13, Nomor 2, Desember 2017

Halaman. 39-56

Kredit Terhadap Peningkatan

Jumlah Nasabah

kreditnya.Oleh karena itu, dari pihak Bank BRI terutama pihak analisis kredit perlumemahami kebijakan pemberian kredit.

Bank BRI (Persero) merupakan salah satu bank milik pemerintah yang masih tetap eksis

untuk melayani masyarakat seperti pemberian kredit baik itu konsumer maupun retailyang mengalami perkembangan lebih baik dari tahun sebelumnya, begitu pula pertumbuhan funding baik itu tabungan maupun deposito hingga profit bank juga mengalami pertumbuhan.

Berdasarkan latar belakang perbankan di atas, maka penulis tertarik untuk melakukan penelitian dengan judul, "Pengaruh prosedur pemberian kredit terhadap peningkatan jumlah nasabah pada Bank BRI Cabang Marisa Kabupaten Pohuwato"

\section{TINJAUAN PUSTAKA}

\section{Pengertian Bank}

Bak berasal dari kata Italia banco yang artinya "bangku", bangku inilah yang dihunakan untuk melakukan kegiatan operasional bank pada masa awal perbankan, istilah bangku secara resmi dan populer menjadi "bank, bank termasuk perusahaan industri jasa, karena aktivitas operasionalnya hanya memberikan pelayanan jasa kepada masyarakat. (Hasibuan, 2006 : 3 ).

Menurut Undang-Undang RI nomor 10 tahun 1998 tanggal 10 November 1998 tentang perbankan adalah badan usaha yang menghimpun dana dari masyarakat dalam bentuk simpanan dan menyalurkannya kepada masyarakat dalam bentuk kredit dan atau bentuk-bentuk lainnya dalam rangka meningkatkan taraf hidup rakyat banyak (Suyatno,2007:152).

Bank sangat penting dan berperan untuk mendorong pertumbuhan perekonomian suatu bangsa karena bank adalah pengumpul dana dari nasabah yang memiliki kelebihan dana dan penyalur kredit kepada nasabah yang kekurangan dana, disamping itu bank juga merupakan suatu tempat menabung yang efektif dan produktif bagi masyarakat, dan juga sebagai pelaksana dalam memperlancar jalannya lalu lintas pembayaran dengan aman, praktis dan ekonomis, serta penjamin penyelesaian perdagangan dengan menerbitkan $\mathrm{L} / \mathrm{C}$ dan penjamin penyelesaian proyek dengan menerbitkan bank garansi.

Berdasarkan definisi di atas, maka dapat disimpulkan bahwa bank merupakan salah satu usaha lembaga keuangan yang bertujuan menghimpun dana dan memberikan kredit serta jasa- 
Pengaruh Prosedur Pemberian

Volume. 13, Nomor 2, Desember 2017

Halaman. 39-56

Kredit Terhadap Peningkatan

Jumlah Nasabah

jasa kepada masyarakat. Adapun pemberian kredit itu dilakukan baik dengan modal sendiri atau dengan dana-dana yang dipercayakan oleh pihak ketiga, maupun dengan jalan memperedarkan alat-alat pembayaran berupa uang giral, dalam rangka meningkatkan taraf hidup orang banyak.

\section{Konsep Prosedur}

Prosedur merupakan rangkaian aktivitas atau kegiatan yang dilakukan secara berulangulang dengan cara yang sama. Prosedur merupakan komponen dari sistem informasi baik itu sistem informasi manajemen atau sistem informasi akuntansi yang sering dilupakan, padahal tanpa prosedur yang benar sistem informasi sehebat apapun tidak akan berjalan sebagaimana mestinya.

Prosedur penting dimiliki bagi suatu organisasi agar segala sesuatu dapat dilakukan secara seragam. Jika prosedur telah diterima oleh pemakai sistem informasi maka prosedur akan menjadi pedoman bagaimana fungsisistem informasi teresebut harus dioperasikan. Dengan adanya prosedur yang memadai, maka pengendalian dapat dilakukan dengan baik.

Aktivitas pada dasarnya merupakan suatu kegiatan berdasarkan informasi yang masuk dan persepsi yang dimiliki tentang informasi tersebut karena itu aktivitas merupakan fungsi dari sistem informasi. Dalam organsiasi terdapat dua macam aktivitas, yaitu aktivitas bisnis dan aktivitas sistem informasi. Aktivitas bisnis merupakan kegiatan yang dilakukan sehari-hari untuk mendukung tujuan organisasi. Sedangkan aktivitas di bidang sistem informasi merupakan kegiatan-kegiatan yang dilakukan untuk mendukung jalannya bisnis perusahaan agar bisa berjalan lebih baik.

Berdasarkan uraian tersebut, maka pengertian prosedurt menurut Rivai, dkk (2006 : 194) adalah rangkaian aktivitas atau kegiatan yang dilakukan secara berulang-ulang dengan cara yang sama. Lebih lanjut ia menjelaskan bahwa prosedur penting dimiliki bagi suatu perusahaan atau organisasi agar segala sesuatu dapat dilakukan secara seragam.

\section{Konsep Kredit}

Begitu populernya kata kredit sehingga istilah kredit bukan hanya masyarakat kota mengenal apa arti kredit tersebut akan tetapi masyarakat dipelosok pedesaanpun sudah tahu 
istilah kredit karena mereka sering berhubungan dengan masalah pinjaman baik melalui dunia perbankan maupun pada lembaga keuangan lainnya seperti halnya koperasi dan juga pegadaian.

Kata kredit berasal dari bahasa latin yaitu credere, yang diterjemahkan sebagai credo yang berarti saya percaya. Kredit dan kepercayaan adalah ibarat sekeping mata uang logam yang tidak dapat dipisahkan. Karena tidak akan mungkin adanya pemberian pinjaman tanpa adanyakepercayaan dan kepercayaan itu adalah sesuatu yang mahal harganya.

Pengertian kredit menurut Undang-undangPasal 1 ayat 11 No. 10 Tahun 1998 perubahan dari Undang-undang No. 7 Tahun 1992 yaitu kredit adalah penyediaan uang atau tagihan-tagihan yang dapat dipersamakan dengan itu, berdasarkan persetujuan atau kesepakatan pinjam meminjam antara bank dengan pihak lain yang mewajibkan pihak peminjam melunasi utangnya setelah jangka waktu tertentu dengan pemberian bunga, imbalan atau pembagian hasil keuntungan. Menurut Muchdarsyah Sinungan dalam Irham Fahmi (2008:5) kredit adalah suatu pemberian prestasi oleh suatu pihak kepada pihak lain dan prestasi itu akan dikembalikan lagi pada suatu masa tertentu yang akan disertai dengan suatu kontraprestasi berupa bunga.

Menurut Triandaru, $\operatorname{dkk}$ (2008: 113) kredit adalah pemberian pinjaman (bukan berdasarkan prinsip syariah) kepada nasabah, baik berupa fasilitas pinjaman tunai (cash loan) maupun pinjaman nontunai (non-chas loan). Kredit pada dasarnya adalah sesuatu yang sangat dibutuhkan oleh masyarakat guna mendorong dan melancarkan aktivitas perdagangan, baik dalam bidang memproduksi barang maupun jasa dan juga untuk meningkatkan atau memenuhi kebutuhan konsumsi masyarakat dengan berbagai defenisinya masing-masing. Menurut Dendawijaya, dkk (2003 : 212) bahwa pada umumnya jenis-jenis kredit perbankan dapat ditinjau dari beberapa sudut, yaitu sebagai berikut :

1. Menurut jangka waktu kredit .

a. Kredit jangka pendek, yaitu kredit yang berjangka waktu maksimum 1 tahun dan biasanya digunakan untuk keperluan modal kerja.

b. Kredit jangka menengah, adalah kredit yang berjangka waktu sampai dengan 3 tahun, kredit jenis ini dapat diberikan untuk modal kerja. 
Pengaruh Prosedur Pemberian

Volume. 13, Nomor 2, Desember 2017

Halaman. 39-56

Kredit Terhadap Peningkatan

Jumlah Nasabah

c. Kredit jangka panjang, adalah kredit yang berjangka waktu lebih dari 3 tahun, biasanya kredit ini digunakan untuk investasi jangka panjang seperti untuk membeli mesin-mesin, alat-alat berat, dan juga untuk kredit konsumtif seperti kredit perumahan.

2. Menurut sifanya

a. Dengan perjanjian, yaitu kredit yang diberikan dengan disertai perjanjian tertulis, penetapan besarnya plafon kredit, suku bunga, jangka waktu, jaminan, dan cara pembayaran.

b. Tanpa perjanjian, yaitu kredit yang diberikan tanpa perjanjian tertulis terlebih dahulu.

3. Menurut kegunaannya.

a. Kredit Modal Kerja

kredit modal kerja adalah fasilitas kredit yang digunakan untuk membiayai aktiva lancar dan atau menggantikan utang dagang serta membiayai sementara kegiatan operasional rutin (sehari-hari) perusahaan (misalnya perusahaan jasa transportasi, perhotelan, rumah makan, dan sebagainya baik yang bersifat langsung maupun tidak langsung.

b. Kredit Konsumsi.

Kredit yang digunakan dalam rangka pengadaan barang atau jasa untuk tujuan konsumsi, dan bukan sebagai barang modal dalam kegiatan usaha nasabah. Penggunaan kredit ini misalnya untuk pembelian mobil, rumah, dan barang-barang konsumsi lain. Kredit ini dipergunakan oleh peminjam untuk keperluan konsumsi.

c. Kredit Investasi.

Biasanya digunakan untuk keperluan perluasan usaha atau membangun proyek/pabrik baru atau untuk keperluan rehabilitasi.

\section{Pemberian Kredit dengan lima C}

Dalam memutuskan pemberian kredit kepada calon nasabah sering kali menggunakan cara - cara statistik untuk menentukan kualitas pelanggan dengan memberikan nilai (skor) tertentu pada pelanggan. Skor nilai ini akan menunjukkan kemungkinan seseorang pelanggan membayar hutangnya, misalnya, skor 1 adalah bagi pelanggan yang memiliki kemungkinan hutangnya macet sebesar dibawah 10\%, skor 2 kemungkinan macet sebesar $10 \%$ sampai $20 \%$, skor 3 kemungkinan macet antara 20\% sampai 30\% dan seterusnya sehingga perusahaan akan mudah dalam memprediksi piutangnya macet, (Agus Marjito, 2012 : 96). 
Pengaruh Prosedur Pemberian

Volume. 13, Nomor 2, Desember 2017

Hataman. 39-56

Kredit Terhadap Peningkatan Jumlah Nasabah

Irham Fahmi (2008 : 13), mengatakan dalam memutuskan pemberian kredit atau melakukan pencarian dana melalui kredit, ada beberapa hal yang harus dipikirkan baik oleh kreditor atau juga debitor secara umum dan itu sudah menjadi penilaian umum, yaitu dengan biasa dikenal dengan Lima C (5C). Prinsip 5C yaitu:

\section{Karakteristik (Character)}

Ini menyangkut dengan sisi psikologis calon penerima kredit itu sendiri, yaitu karakteristik atau sifat yang dimilikinya, seperti latar belakang keluarganya, hobi, cara hidup yang dijalani, kebiasaan-kebiasaannya. Tinjauan karakteristik ini bisa dilihat dalam hal bagaimana ia melakukan keputusan bisnis selama ini dalam hal ketepatan waktu yang menyangkut dengan perjanjian atau kesepakatan-kesepakatan yang telah dilakukan selama ini. Kita bisa melakukan pengecekan kepada pihak-pihak yang telah menjadi mitra bisnisnya selama ini, yaitu menyangkut kepuasan dan juga kedisiplinannya menyelesaikan hal-hal yang berhubungan dengan financial seperti penyelesaian hutang dagang. Pada prinsipnya jika sebuah perusahaan ingin benar-benar dinilai dari segi karakteristik ini tentunya ini semua tertuju kepada penilaian kejujuran pihak manajemen dalam mengelola perusahaan selama ini. Karena itu, analisis dengan pendekatan human resource dan aspek psikologi sangat tidak bisa dikesampingkan. Sehingga tidak mengherankan jika kita melihat mengapa pada perusahaan-perusahaan yang berskala menengah ke atas terutama perusahaan yang go public bahwa kepada setiap manajer yang diterima disana dilakukan uji seperti fit and propertest, yang tujuannya tidak lain untuk melihat sisi yang lebih dalam dari diri seorang calon manajer tersebut. Karakteristik ini juga menyangkut persoalan seperti kejujuran seorang nasabah dalam urusannya untuk berusaha memenuhi kewajibannya.

\section{Kemampuan (Capacity)}

Capacity adalah menyangkut dengan business record atau kemampuan seorang pebisnis mengelola usahanya, terutama pada masa-masa sulit sehingga nanti akan terlihat kemampuan dalam membayar yang dimiliki oleh setiap orang berbeda-beda. Setiap orang memiliki bakatnya masing-masing atau keahliannya yang berbeda dengan orang lain dan itu pada dasarnya telah menjadi keunggulan yang lebih dibandingkan dengan orang lain. Karena itu pada saat seseorang memutuskan untuk masuk kedalam satu sektor bisnis dan 
memulai bisnis tersebut, yang menjadi persoalannya apakah bisnis yang dijalaninya adalah bisnis yang sesuai dengan bakat dan minat yang dimilikinya atau lebih pada sebuah keputusan yang sifatnya melihat pada sisi trend saja. Yang harus kita pahami dalam konsep investasi ada beberapa faktor yang selalu saja mengganggu atau membuat sebuah sektor bisnis itu mengalami masalah atau yang dikenal dengan istilah resiko bisnis. Karena itu, bagi seorang pebisnis akan lebih baik jika ia melakukan aktivitas bisnis dengan memperhatikan berbagai resiko yang mungkin timbul jika bisnis seperti ini diambil dan juga apa tindakan yang akan diambil jika resiko yang seperti itu terjadi kelak.

\section{Modal (Capital)}

Ini menyangkut dengan kemampuan modal yang dimiliki oleh seseorang pada saat dia melaksanakan bisnisnya tersebut. Capital ini secara umum dapat dilihat pada balancesheet, income statement, capital structure, return on equity, return on investment. Hal Ini akan lebih baik jika ia melakukan peminjaman kepada pihak perbankan atau leasing sehingga angka pengajuan kreditnya tersebut mnlebihi dari kepemilikan modal yang dipunyainya, jelas ini akan menimbulkan risiko dikemudian hari apa lagi jika terjadi persoalan kemacetan dalam cash flow.

\section{Jaminan (Collateral)}

Collateral atau yang biasa disebut dengan jaminan adalah barang atau sesuatu yang dapat dijadikan jaminan pada saat seseorang akan melakukan peminjaman dana dalam bentuk kredit kesebuah perbankan atau leasing. Untuk jenis barang ini dapat berupa mulai dari tanah. Bangunan. Mobil. Motor. Atau juga pesawat. Helikopter juga bisa dijadikan jaminan. Dan juga barang lainnya yang kira-kira dapat disetujui oleh pihak analis kredit. Pada seorang karyawan tetap disebuah perusahaan. Jika pada saat ia mengajukan pinjaman kredit, maka ia dapat memperlihatkan slip gaji yang dimilikinya. Misalnya surat keputusan pengangkatanya sebagai pegawai, dan beberapa surat lain yang dianggap sebagai pendukung sebagai kartu keluarga (KK), Kartu Tanda Penduduk (KTP) dan lainnya lagi yang dianggap bisa menjadi salah satu pendukung dan dapat dipergunakan dengan alasan bisa dipertanggungjawabkan dikemudian hari. Selain yang disebutkan diatas, jabatan yang dipegang oleh seseorang juga bisa menjadi sebuah jaminan jika jabatan itu memungkinkan 
Pengaruh Prosedur Pemberian

Volume. 13, Nomor 2, Desember 2017

Halaman. 39-56

Kredit Terhadap Peningkatan

Jumlah Nasabah

dan dapat diterima sebagai suatu bagian yang dapat dipertanggungjawabkan di kemudian hari, seperti jabatan seorang gubernur dan mentri.

\section{Kondisi perekonomian (Condition Of Economy)}

Kondisi perekonomian yang tengah berlangsung disuatu Negara seperti tingkat pertumbuhan ekonomi yang tengah terjadi, angka inflasi, jumlah pengangguran, daya beli penerapan kebijakan moniter sekarang dan yang akan datang, dan iklim dunia usaha yaitu regulasi pemerintah, serta situasi ekonomi internasional yang tengah berkembang adalah bagian piutang untuk dianalisis dan dijadikan bahan pertimbangan. Bagi analis yunior bidang kredit atau bagi pihak yang akan memulai usaha serta juga bagi mereka yang tidak berlatarbelakang pendidikan ekonomi dan juga masih banyak memiliki kekurangan dalam memahami persoalan condition of economy pada suatu Negara, ada baiknya untuk tahap ini adalah mencari informasi terlebih dahulu dari mereka yang telah lama berkecimpung dalam masalah kredit atau setidaknya meminta pendapat dari para ahli ekonomi. Karena kesalahan banyak terjadi pada mereka yang meminjam danadari pihak perbankan atau mengambil kredit adalah berdasarkan keputusan yang tidak di back up oleh dasar-dasar yang kuat, tetapi lebih pada intuisi dan perkiraan yang sederhana saja tanpa mempertimbang kan banyak segi dan faktor, khususnya faktor makro ekonomi. Bukan tidak mungkin kita banyak sekali menemukan bukti yang memperlihatkan bahwa pada mereka yang melakukan seperti itu dalam perjalanan usahanya mengalami masalah dalam mengembalikan pinjaman yang telah dimilikinya tersebut yang bisa jadi karena faktor penurunan keuntungan dari yang diprediksi semula.

\section{Pengertian Nasabah}

Nasabah diibaratkan nafas yang sangat berpengaruh terhadap kelanjutan suatu bank. Oleh karena itu bank harus dapat menarik nasabah sebanyak-banyaknya agar dana yang sudah dihimpun tersebut dapat diputar oleh bank yang nantinya dipinjamkan kepada calon nasabah yang butuh pinjam dari pihak bank. Nasabah memiliki peranan yang sangat penting dalam suatu bank karena nasabah membutuhkan jasa bank seperti halnya tabungan, kredit, deposito, ataupun jasa-jasa lainnya. Begitu juga dengan bank sangat memerlukan peran seorang nasabah dalam rangka menjaga kontinuitas usaha dapat terus beroperasi, berkembang, menikmati laba. Menurut 
Pengaruh Prosedur Pemberian

Volume. 13, Nomor 2, Desember 2017

Halaman. 39-56

Kredit Terhadap Peningkatan

Jumlah Nasabah

Kamus Besar Bahasa Indonesia, nasabah merupakan orang yang biasa berhubungan dengan atau menjadi pelanggan bank (dalam hal keuangan). (https://.web.id/nasabah.html, update, 17 September 2017).

Menurut Djaslim Saladin (1994:84) dalam bukunya "Dasar-Dasar Manajemen Pemasaran Bank" yang dikutip dari "Kamus Perbankan" menyatakan bahwa "Nasabah atau mitra adalah orang atau badan yang mempunyai rekening simpanan atau pinjaman pada bank. Komaruddin (1994:102) dalam "Kamus Perbankan" menyatakan bahwa "Nasabah adalah seseorang atau suatu perusahaan yang mempunyai rekening koran atau deposito atau tabungan serupa lainnya pada sebuah bank".Sedangkan Puspopranoto, dkk (2004:114) mengartikan nasabah sebagai orang yang sangat berhubungan dengan bank yang berperan sebagai peminjam dan penabung dalam suatu Bank tersebut. Meningkatnya jumlah nasabah memberikan andil yang cukup besar pada pertumbuhan laba bank. Semakin besar jumlah nasabah yang dimiliki oleh bank, maka semakin besar pula kesempatan untuk memperbesar laba bank. Hal itu dikarenakan nasabah merupakan aktor penting dalam menjaga kelangsungan usaha perbankan dalam mencari keuntungan. Sehingga tanpa adanya nasabah usaha bank dalam melayani dan mencari keuntungan, tidak akan bisa terlaksana sesuai dengan yang harapkan.

\section{Metodologi Penelitian}

\section{Desain penelitian}

Metode penelitian yang dilakukan oleh penulis adalah penelitian survei. Menurut Klinger (1996) dalam Riduwan (2010:49) bahwa "penelitian survei adalah penelitian yang dilakukan pada populasi besar maupun kecil, tetapi data yang dipelajari adalah data dari sampel yang diambil dari populasi tersebut, sehingga ditemukan kejadian-kejadian relatif, distribusi, dan hubungan antar variabel sosiologis maupun psikologis.

\section{Metode Analisis}

Dalam penelitian ini digunakan metode analisis regresi berganda (multiple regression), yaitu metode analisis yang digunakan untuk mengukur besarnya pengaruh variabel bebas yaitu prosedur pemberian kredit $(\mathrm{X})$ berupa Character $\left(\mathrm{X}_{1}\right)$, Capacity $\left(\mathrm{X}_{2}\right)$, Capital $\left(\mathrm{X}_{3}\right)$, Collateral 
$\left(\mathrm{X}_{4}\right)$ dan Condition of Economy $\left(\mathrm{X}_{5}\right)$ pengaruhnya terhadap variabel terikat yaitu peningkatan jumlah nasabah (Y). Adapun persamaan regresinya adalah sebagai berikut.

$$
\mathrm{Y}=\alpha+\beta 1 X 1+\beta 2 X 2+\beta 3 X 3+\beta 4 X 4+\beta 5 X 5+\varepsilon
$$

Dimana:

$\boldsymbol{\varepsilon} \quad=$ Standar error atau variabel yang tidak diteliti

$\mathrm{Y} \quad=$ Peningkatan jumlah nasabah

$\alpha=$ Nilai konstan atau nilai tetap

$\beta_{1}-\beta_{5}=$ Parameter (koefisien variabel)

$\mathrm{X}_{1}=$ Character

$\mathrm{X}_{2}=$ Capacity

$\mathrm{X}_{3}=$ Capital

$\mathrm{X}_{4}=$ Collateral

$\mathrm{X}_{5}=$ Condition of Economy

\section{HASIL PENELITIAN}

\section{Pengujian Kualitas Data}

Menurut Sugiyono (2002), instrumen yang dinyatakan valid dan reliabel adalah instrumen yang valid berarti alat ukur yang digunakan untuk mengukur data itu valid. Adapun hasil uji validitas dan uji reliabilitas pada penelitian ini adalah sebagai berikut:

\section{Pengujian Validitas}

Untuk menguji kualitas validitas kuesioneryaitu membandingkan $r$ tabel dengan $r$ hitung. Nilai $r$ tabel dapat dilihat pada tabel $r$ dengan $\mathrm{df}=\mathrm{n}-2(\mathrm{n}=$ jumlah responden/sampel $)$. Pada tingkat kemaknaan 5\%, maka akan didapatkan angka $r$ tabel. Nilai $r$ hasil/output SPSS dapat dilihat pada kolom "Corrected item-Total Correlation". Pengambilan keputusan dari masingmasing pernyataan/pertanyaan dibandingkan nilai $r$ hasil/output dengan nilai $r$ tabel, bila $r$ hasil > $\mathrm{r}$ tabel, maka dapat dikatakan valid dan apabila $\mathrm{r}$ hasil< $\mathrm{r}$ tabel, maka dikatakan tidak valid (Ghozali, 2005), Sebagaimana pada Tabel 1.berikut. 
Tabel 1.Hasil Uji Validitas variabel Prosedur Pemberian Kredit berupa Character $\left(\mathrm{X}_{1}\right)$

\begin{tabular}{l|r|r|r|r}
\hline & \multicolumn{3}{|c|}{ Item-Total Statistics } \\
\hline & \multicolumn{1}{|c|}{$\begin{array}{c}\text { Scale Mean if Item } \\
\text { Deleted }\end{array}$} & $\begin{array}{l}\text { Scale Variance } \\
\text { if Item Deleted }\end{array}$ & $\begin{array}{c}\text { Corrected Item-Total } \\
\text { Correlation }\end{array}$ & $\mathrm{r}$ tabel \\
\hline $\mathrm{X}_{1.1}$ & 12.6071 & 1.655 & 1.450 & .694 \\
$\mathrm{X}_{1.2}$ & 12.7500 & 1.231 & 1.852 & .690 \\
$\mathrm{X}_{1.3}$ & 12.6786 & 1.189 & 1.755 & .684 \\
$\mathrm{X}_{1.4}$ & 12.5357 & 1.443 & 1.378 & .636 \\
\hline
\end{tabular}

Sumber : Data diolah, 2017

Hasil uji validitas variabel prosedur pemberian kredit berupa character $\left(\mathrm{X}_{1}\right)$ pada Tabel 1 . di atas dari keempat butir pernyataan/pertanyaan semuanya valid karena nilai Corrected itemTotal Correlation > dari 0,30, dan"Corrected item-Total Correlation" memiliki nilai > dari $\mathrm{r}$ tabel (0,361).

Tabel 2. Hasil Pengujian Validitas Variabel Prosedur Pemberian Kredit berupaCapacity $\left(\mathrm{X}_{2}\right)$

\begin{tabular}{l|r|r|r|r}
\hline \multicolumn{5}{c}{ Item-Total Statistics } \\
\hline & Scale Mean if Item Deleted & Scale Variance if Item Deleted & $\begin{array}{c}\text { Corrected Item-Total } \\
\text { Correlation }\end{array}$ & r tabel \\
\hline$X_{2.1}$ & 12.3571 & 1.127 & .359 & .627 \\
$X_{2.2}$ & 12.2143 & 1.656 & .424 & .700 \\
$X_{2.3}$ & 12.4643 & .999 & .365 & .629 \\
$X_{2.4}$ & 12.2500 & .861 & .341 & .797 \\
\hline
\end{tabular}

Sumber :data olahan, 2017

Hasil uji validitas variabel prosedur pemberian kredit berupa capacity $\left(\mathrm{X}_{2}\right)$ pada Tabel 2. di atas dari keempat butir pernyataan/pertanyaan semuanya valid karena nilai Corrected item-Total Correlation > dari 0,30, dan "Corrected item-Total Correlation" memiliki nilai > dari $\mathrm{r}$ tabel $(0,361)$.

Tabel 3. Hasil Pengujian Validitas Variabel Prosedur Pemberian Kredit berupaCapital $\left(\mathrm{X}_{3}\right)$

\begin{tabular}{l|r|r|r|r}
\hline \multicolumn{5}{|c}{ Item-Total Statistics } \\
\hline & Scale Mean if Item Deleted & Scale Variance if Item Deleted & Corrected Item-Total Correlation & $\mathrm{r}$ tabel \\
\hline X3.1 & 12.2143 & 1.138 & .322 & .629 \\
X3.2 & 12.2857 & 1.175 & .347 & .716 \\
X3.3 & 12.3214 & 1.115 & .389 & .758 \\
X3.4 & 12.3571 & 1.127 & .335 & .662 \\
\hline
\end{tabular}

Sumber :data olahan, 2017 
Hasil uji validitas variabel prosedur pemberian kredit berupa capacity $\left(\mathrm{X}_{3}\right)$ pada Tabel 3. di atas dari keempat butir pernyataan/ pertanyaan semuanya valid karena nilai Corrected item-Total Correlation > dari 0,30, dan "Corrected item-Total Correlation" memiliki nilai > dari $\mathrm{r}$ tabel $(0,361)$.

Tabel 4. Hasil Pengujian Validitas Variabel Prosedur Pemberian Kredit berupa Capacity $\left(\mathrm{X}_{4}\right)$

\begin{tabular}{|c|c|c|c|c|}
\hline \multicolumn{5}{|c|}{ Item-Total Statistics } \\
\hline & Scale Mean if Item Deleted & Scale Variance if Item Deleted & $\begin{array}{c}\text { Corrected Item-Total } \\
\text { Correlation }\end{array}$ & $\mathrm{r}$ tabel \\
\hline $\mathrm{X}_{4.1}$ & 12.8214 & 1.263 & .324 & .644 \\
\hline $\mathrm{X}_{4.2}$ & 12.7143 & 1.101 & .305 & .632 \\
\hline $\mathrm{X}_{4.3}$ & 12.7857 & 1.915 & .319 & .639 \\
\hline$X_{4.4}$ & 12.4643 & 1.999 & .327 & .648 \\
\hline
\end{tabular}

Sumber :data olahan, 2017

Hasil uji validitas variabel prosedur pemberian kredit berupa capacity $\left(\mathrm{X}_{4}\right)$ pada Tabel 4. di atas dari keempat butir pernyataan/ pertanyaan semuanya valid karena nilai Corrected item-Total Correlation > dari 0,30, dan "Corrected item-Total Correlation" memiliki nilai > dari $\mathrm{r}$ tabel $(0,361)$.

Tabel 5. Hasil Uji Validitas variabel Prosedur Pemberian Kredit berupa Condition Of Economy $\left(\mathrm{X}_{5}\right)$

\begin{tabular}{l|r|r|r|r}
\hline \multicolumn{5}{|c|}{ Item-Total Statistics } \\
\hline & Scale Mean if Item Deleted & \multicolumn{1}{|c|}{$\begin{array}{l}\text { Scale Variance } \\
\text { if Item Deleted }\end{array}$} & Corrected Item-Total Correlation & r tabel \\
\hline$X_{5.1}$ & 13.0000 & 1.481 & .379 & .642 \\
$X_{5.2}$ & 12.9286 & 1.476 & .374 & .630 \\
$X_{5.3}$ & 12.5000 & 1.815 & .486 & .692 \\
$X_{5.4}$ & 12.5714 & 1.958 & .393 & .670 \\
\hline
\end{tabular}

Sumber :Data olahan, 2017

Hasil uji validitas variabel prosedur pemberian kredit berupa Condition Of Economy $\left(\mathrm{X}_{5}\right)$ pada Tabel 5. di atas dari keempat butir pernyataan/ pertanyaan semuanya valid karena nilai Corrected item-Total Correlation > dari 0,30, dan "Corrected item-Total Correlation" memiliki nilai > dari r tabel $(0,361)$. 
Tabel.6. Hasil Pengujian Validitas variabel Peningkatan Jumlah Nasabah (Y)

\begin{tabular}{r|r|r|r|r}
\hline \multicolumn{5}{|c}{ Item-Total Statistics } \\
\hline & Scale Mean if Item Deleted & Scale Variance if Item Deleted & Corrected Item-Total Correlation & $\mathrm{r}$ tabel \\
\hline $\mathrm{Y}_{1.1}$ & 29.8571 & 7.608 & .393 & .716 \\
$\mathrm{Y}_{1.2}$ & 29.8929 & 7.581 & .526 & .688 \\
$\mathrm{Y}_{1.3}$ & 29.8214 & 7.708 & .454 & .702 \\
$\mathrm{Y}_{1.4}$ & 29.9643 & 8.480 & .420 & .753 \\
$\mathrm{Y}_{1.5}$ & 29.8571 & 7.757 & .453 & .702 \\
$\mathrm{Y}_{1.6}$ & 29.8214 & 8.152 & .377 & .717 \\
$\mathrm{Y}_{1.7}$ & 29.7857 & 7.878 & .451 & .703 \\
$\mathrm{Y}_{1.8}$ & 29.7500 & 7.157 & .602 & .671 \\
\hline
\end{tabular}

Sumber : data olahan, 2017

Dari hasil pengujian validitas variabel peningkatan jumlah nasabah (Y) pada Tabel. 6. di atas dari kedelapan butir pernyataan/pertanyaan semuanya valid karena nilai Corrected itemTotal Correlation> dari r tabel $(0,455)$.

Berdasarkan data olahan dari keenam variabel di atas yakni variable $\mathrm{X}$ dan variable $\mathrm{Y}$, maka dapat disimpulkan bahwa semua butir variabel penerapan lima $\mathrm{C}$ dari sudah valid baik menurut Sugiyono (2002) maupun apabila dibandingkan dengan nilai $r$ tabel.

\section{Pengujian Reliabilitas}

Apabila responden konsisten dalam menjawab pertanyaan dalam angket, maka data tersebut adalah reliabel. Suatu konstruk atau variabel dikatakan reliabel jika uji statistik SPSS memberikan nilai $\alpha>0,60$, Ghozali (2005). Pengujian reliabilitas dalam penelitian ini adalah dengan menggunakan rumus alpha.

Hasil pengujian reliabilitas untuk masing-masing variabel diperoleh data sebagaimana pada Tabel.7.berikut.

Tabel. 7. Uji Reliabilas Instrumen

Reliability Statistics

\begin{tabular}{|c|c|c|c|}
\hline Variabel & $\begin{array}{l}\mathrm{N} \text { of } \\
\text { Items }\end{array}$ & Cronbach's Alpha & Ket. \\
\hline Character(X1) & 4 & 619 & Reliabel \\
\hline Capacity (X2) & 4 & .635 & Reliabel \\
\hline Capital (X3) & 4 & .658 & Reliabel \\
\hline Collateral (X4) & 4 & .629 & Reliabel \\
\hline Condition of Economy (X5) & 4 & .621 & Reliabel \\
\hline Peningkatan Jumlah Nasbah (Y) & 8 & .734 & Reliabel \\
\hline
\end{tabular}

Sumber :data olahan, 2017 
Semua variabel dalam penelitian mempunyai koefisien alpha $(\alpha)$ yang cukup besar yaitu > 0,60, sehingga dapat dikatakan semua konsep pengukuran masing-masing variabel dari kuesioner adalah reliabel berarti bahwa koesioner yang digunakan dalam penelitian ini adalah kuesioner yang handal. Suatu konstruk dikatakan reliabel jika uji statistik SPSS memberikan nilai $\alpha>0,60$. Ghozali (2005).

\section{Analisis Regresi Linier Berganda}

Analisis regresi linear berganda digunakan untuk mengetahui pengaruh variabel independen pada penelitian ini yaitu prosedur pemberian kredit $(\mathrm{X})$ berupa Character $\left(\mathrm{X}_{1}\right)$, Capacity $\left(\mathrm{X}_{2}\right)$, Capital $\left(\mathrm{X}_{3}\right)$, Collateral $\left(\mathrm{X}_{4}\right)$, dan Condition of Economy $\left(\mathrm{X}_{5}\right)$ terhadap variabel dependen yaitu peningkatan jumlah nasabah (Y). Hasil perhitungan regresi berganda dengan menggunakan program SPSS, secara ringkas dapat dilihat pada Tabel. 8. berikut.

Tabel.8. Ringkasan Hasi Analisis Regresi

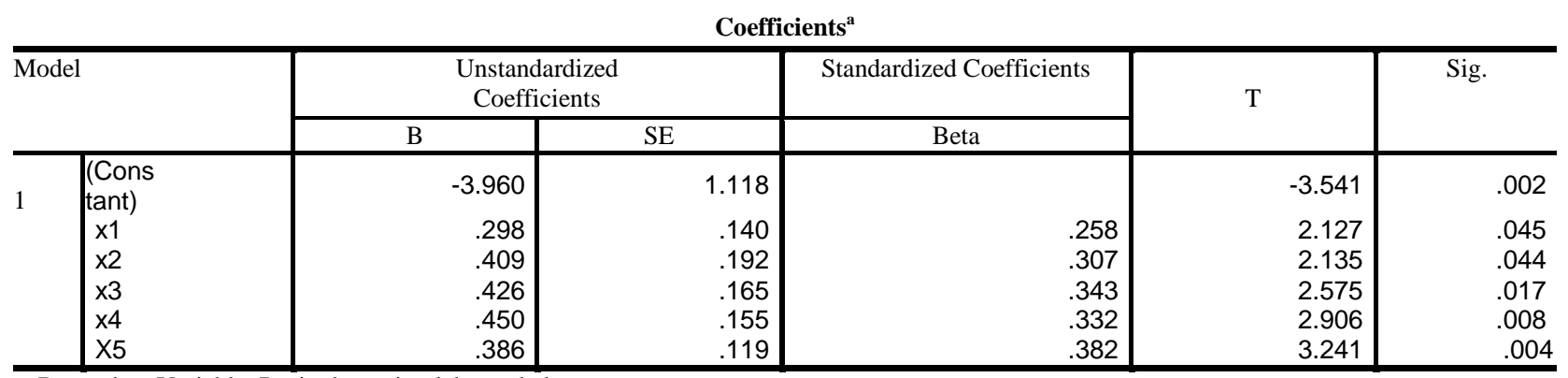

a. Dependent Variable: Peningkatan jumlah nasabah

Sumber : data primer, diolah 2017

$$
Y=-3,960+0,298 X_{1}+0,409 X_{2}+0,426 X_{3}+0,450 X_{4}+0,386 X_{5}
$$

Dari persamaan tersebut, dapat dijelaskan bahwa nilai koefisien regresi variabel prosedur pemberian kredit berupa Character $\left(\mathrm{X}_{1}\right)$ sebesar 0,298, hal ini berarti bahwa perubahan variabel Character $\left(\mathrm{X}_{1}\right)$ akan diikuti oleh perubahan peningkatan jumlah nasabah sebesar 0,298 dengan asumsi variabel lainnya konstan. Koefisien regresi variabel prosedur pemberian kredit berupa Capacity $\left(\mathrm{X}_{2}\right)$ sebesar 0,409 . Ini berarti bahwa perubahan variabel Capacity $\left(\mathrm{X}_{2}\right)$ akan diikuti 
Pengaruh Prosedur Pemberian

Volume. 13, Nomor 2, Desember 2017

Halaman. 39-56

Kredit Terhadap Peningkatan

Jumlah Nasabah

oleh perubahan peningkatan jumlah nasabah sebesar 0,409 dengan asumsi variabel lainnya konstan.

Koefisien regresi variabel prosedur pemberian kredit berupa Capital $\left(\mathrm{X}_{3}\right)$ sebesar 0,426.

Ini berarti bahwa perubahan variabel Capital $\left(\mathrm{X}_{3}\right)$ akan diikuti oleh perubahan peningkatan jumlah nasabah sebesar 0,426 dengan asumsi variabel lainnya konstan. Koefisien regresi variabel prosedur pemberian kredit berupa Collateral $\left(\mathrm{X}_{4}\right)$ sebesar 0,450, hal ini berarti bahwa perubahan variabel Collateral $\left(\mathrm{X}_{4}\right)$ akan diikuti oleh perubahan peningkatan jumlah nasabah sebesar 0,450 dengan asumsi variabel lainnya konstan.

Koefisien regresi variabel prosedur pemberian kredit berupa Condition of Economy $\left(\mathrm{X}_{5}\right)$ sebesar 0,386, hal ini berarti bahwa perubahan variabel Condition of Economy $\left(\mathrm{X}_{5}\right)$ akan diikuti oleh perubahan peningkatan jumlah nasabah sebesar 0,386 dengan asumsi variabel lainnya konstan. Persamaan regresi di atas juga menunjukkan nilai konstanta sebesar -3,960 yang berarti bahwa nilai peningkatan jumlah nasabah sebesar -3,960 jika variabel prosedur pemberian kredit (X) berupa Character $\left(\mathrm{X}_{1}\right)$, Capacity $\left(\mathrm{X}_{2}\right)$, Capital $\left(\mathrm{X}_{3}\right)$, Collateral $\left(\mathrm{X}_{4}\right)$, dan Condition of Economy $\left(\mathrm{X}_{5}\right)$ bernilai 0 .

Selanjutnya variasi naik turunnya variabel peningkatan jumlah nasabah dapat dilihat melalui nilai koefisien determinasi $\left(\mathrm{R}^{2}\right)$ dengan model summary pada Tabel. 9 di bawah ini.

Tabel. 9 Nilai Koefisien Determinasi $\left(\mathrm{R}^{2}\right)$

\begin{tabular}{c|r|r|r|r}
\hline \multicolumn{2}{|c|}{ Model Summary } \\
\hline Model & R & R Square & Adjusted R Square & Std. Error of the Estimate \\
\hline 1 & $.847^{\mathrm{a}}$ & .717 & .652 & .22980 \\
\hline
\end{tabular}

a. Predictors: (Constant), $\mathrm{X}_{5}, \mathrm{X}_{3}, \mathrm{X} 4, \mathrm{X}_{1}, \mathrm{X}_{2}$

b. Dependent Variable: $Y$

Sumber : data primer, diolah 2017

Nilai koefisien determinasi $\left(\mathrm{R}^{2}\right)$ pada tabel di atas menunjukkan angka 0,717 atau 71,70\%, memiliki makna bahwa 71,70\% variasi naik turunnya variabel peningkatan jumlah nasabah Bank BRI Cabang Marisa Kabupaten Pohuwato (Y) mampu dijelaskan oleh variabel prosedur pemberian kredit $(\mathrm{X})$ berupa Character $\left(\mathrm{X}_{1}\right)$, Capacity $\left(\mathrm{X}_{2}\right)$, Capital $\left(\mathrm{X}_{3}\right)$, Collateral 
Pengaruh Prosedur Pemberian

Volume. 13, Nomor 2, Desember 2017

Halaman. 39-56

Kredit Terhadap Peningkatan Jumlah Nasabah

$\left(\mathrm{X}_{4}\right)$, dan Condition of Economy $\left(\mathrm{X}_{5}\right)$. Sedangkan sisanya sebesar $100-71,70=28,30 \%$ dijelaskan oleh variabel lain di luar model.

\section{Uji Hipotesis}

\section{Uji Parsial ( Uji-t)}

Uji-t digunakan untuk membandingkan nilai $t_{\text {tabel }}$ dan nilai $t_{\text {hitung }}$ pada taraf signifikansi 0,05. Jika nilai $t_{\text {hitung }}$ lebih besar dari nilai $t_{\text {tabel }}\left(t_{\text {hitung }}>t_{\text {tabel }}\right)$, maka hipotesis penelitian diterima. Sebaliknya jikanilai $t_{\text {hitung }}$ lebih kecil dari nilai $t_{\text {tabel }}\left(t_{\text {hitung }}<t_{\text {tabel }}\right)$, maka hipotesis penelitian ditolak. Adapun nilai $\mathrm{t}_{\text {tabel }}$ menggunakan signifikansi $(\alpha)=5 \%=0.05$, dan nilai df sebesar $\mathrm{n}-\mathrm{k}$, dimana $\mathrm{n}$ = banyaknya sampel/observasi, $\mathrm{K}=$ jumlah variabel yang diteliti (variabel bebas + variabel terikat), sehingga dalam penelitian ini, $n=40$ dan $k=6(5+1)$, jadi df $=40-6=34$ sedangkan nilai t-tabel diperoleh sebesar 2,032.

Uji signifikansi juga dapat dilihat dari nilai signifikansi koefisien regresi. Jika nilai signifikansi lebih kecil dari 0,05 maka hipotesis penelitian dapat diterima. Sebaliknya jika nilai signifikansi lebih besar dari 0,05 maka hipotesis penelitian ditolak.

\section{a. Pengujian Hipotesis Pertama $\left(\mathrm{H}_{1}\right)$}

Pengaruh prosedur pemberian kredit berupa Character $\left(\mathrm{X}_{1}\right)$ terhadap peningkatan jumlah nasabah pada Bank BRI Cabang Marisa Kabupaten Pohuwato dispesifikasikan dalam hipotesis pertama $\left(\mathrm{H}_{1}\right)$ yaitu:

$\mathrm{H}_{1}$ :Prosedur pemberian kredit berupa Character $\left(\mathrm{X}_{1}\right)$ berpengaruh positif dan siginifikan terhadap peningkatan jumlah nasabah pada Bank BRI Cabang Marisa Kabupaten Pohuwato.

Berdasarkan perhitungan analisis regresi berganda diperoleh nilai $t_{\text {hitung }}$ sebesar 2,127. Nilai ini lebih besar dari nilai $t_{\text {tabel }} 2,032$, yang berarti bahwa prosedur pemberian kredit berupa Character $\left(\mathrm{X}_{1}\right)$ berpengaruh positif dan siginifikan terhadap peningkatan jumlah nasabah pada Bank BRI Cabang Marisa Kabupaten Pohuwato. hal ini juga didukung dengan nilai signifikansi sebesar 0,045 yang lebih kecil daripada tingkat kemaknaan 5\% $(0,045<0,05)$. Dengan demikian dapat dikatakan bahwa hipotesis penelitian yang menyatakan prosedur pemberian kredit berupa Character $\left(\mathrm{X}_{1}\right)$ berpengaruh positif dan siginifikan terhadap peningkatan jumlah nasabah pada Bank BRI Cabang Marisa Kabupaten Pohuwatoditerima. 
Pengaruh Prosedur Pemberian

Volume. 13, Nomor 2, Desember 2017

Halaman. 39-56

Kredit Terhadap Peningkatan

Jumlah Nasabah

\section{b. Pengujian Hipotesis Kedua $\left(\mathbf{H}_{2}\right)$}

Pengaruh prosedur pemberian kredit berupa Capacity $\left(\mathrm{X}_{2}\right)$ terhadap peningkatan jumlah nasabah pada Bank BRI Cabang Marisa Kabupaten Pohuwato dispesifikasikan dalam hipotesis kedua $\left(\mathrm{H}_{2}\right)$ yaitu:

$\mathrm{H}_{2}$ :Prosedur pemberian kredit berupa Capacity $\left(\mathrm{X}_{2}\right)$ berpengaruh positif dan siginifikan terhadap peningkatan jumlah nasabah pada Bank BRI Cabang Marisa Kabupaten Pohuwato.

Berdasarkan hitungan analisis regresi berganda diperoleh nilai $t_{\text {hitung }}$ sebesar2,135. Nilai ini lebih besar dari nilai $\mathrm{t}_{\text {tabel }} 2,032$, yang berarti bahwa prosedur pemberian kredit berupa Capacity $\left(\mathrm{X}_{2}\right)$ berpengaruh positif dan siginifikan terhadap peningkatan jumlah nasabah pada Bank BRI Cabang Marisa Kabupaten Pohuwato. hal ini juga didukung dengan nilai signifikansi sebesar 0,044 yang lebih kecil daripada tingkat kemaknaan 5\% $(0,044<0,05)$. Dengan demikian dapat dikatakan bahwa hipotesis penelitian yang menyatakan prosedur pemberian kredit berupa Capacity $\left(\mathrm{X}_{2}\right)$ berpengaruh positif dan siginifikan terhadap peningkatan jumlah nasabah pada Bank BRI Cabang Marisa Kabupaten Pohuwato diterima.

\section{c. Pengujian Hipotesis Ketiga $\left(\mathrm{H}_{3}\right)$}

Pengaruh prosedur pemberian kredit berupa Capital $\left(\mathrm{X}_{3}\right)$ terhadap peningkatan jumlah nasabah pada Bank BRI Cabang Marisa Kabupaten Pohuwato dispesifikasikan dalam hipotesis ketiga $\left(\mathrm{H}_{3}\right)$ yaitu:

H3: Prosedur pemberian kredit berupa Capital $\left(\mathrm{X}_{3}\right)$ berpengaruh positif dan siginifikan terhadap peningkatan jumlah nasabah pada Bank BRI Cabang Marisa Kabupaten Pohuwato.

Berdasarkan perhitungan analisis regresi berganda diperoleh nilai $t_{\text {hitung }}$ sebesar 2,575. Nilai ini lebih besar dari nilai $t_{\text {tabel }} 2,032$, yang berarti bahwa prosedur pemberian kredit berupa Capital $\left(\mathrm{X}_{3}\right)$ berpengaruh positif dan siginifikan terhadap peningkatan jumlah nasabah pada Bank BRI Cabang Marisa Kabupaten Pohuwato. hal ini juga didukung dengan nilai signifikansi sebesar 0,017 yang lebih kecil dari pada tingkat kemaknaan $5 \%(0,017<0,05)$. Dengan demikian dapat dikatakan bahwa hipotesis penelitian yang menyatakan prosedur pemberian kredit berupa Capital 
Pengaruh Prosedur Pemberian

Volume. 13, Nomor 2, Desember 2017

Halaman. 39-56

Kredit Terhadap Peningkatan

Jumlah Nasabah

$\left(\mathrm{X}_{3}\right)$ berpengaruh positif dan siginifikan terhadap peningkatan jumlah nasabah pada Bank BRI Cabang Marisa Kabupaten Pohuwato diterima.

\section{d. Pengujian Hipotesis Keempat $\left(\mathrm{H}_{4}\right)$}

Pengaruh prosedur pemberian kredit berupa Collateral $\left(\mathrm{X}_{4}\right)$ terhadap peningkatan jumlah nasabah pada Bank BRI Cabang Marisa Kabupaten Pohuwatodispesifikasikan dalam hipotesis keempat $\left(\mathrm{H}_{4}\right)$ yaitu:

H4:Prosedur pemberian kredit berupa Capital $\left(\mathrm{X}_{4}\right)$ berpengaruh positif dan siginifikan terhadap peningkatan jumlah nasabah pada Bank BRI Cabang Marisa Kabupaten Pohuwato.

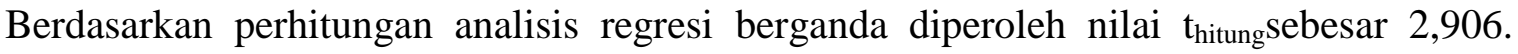
Nilai ini lebih besar dari nilai $t_{\text {tabel }} 2,032$, yang berarti bahwa prosedur pemberian kredit berupa Collateral $\left(\mathrm{X}_{4}\right)$ berpengaruh positif dan siginifikan terhadap peningkatan jumlah nasabah pada Bank BRI Cabang Marisa Kabupaten Pohuwato. hal ini juga didukung dengan nilai signifikansi sebesar 0,008 yang lebih kecil daripada tingkat kemaknaan 5\% $(0,008<0,05)$. Dengan demikian dapat dikatakan bahwa hipotesis penelitian yang menyatakan prosedur pemberian kredit berupa Collateral $\left(\mathrm{X}_{4}\right)$ berpengaruh positif dan siginifikan terhadap peningkatan jumlah nasabah pada Bank BRI Cabang Marisa Kabupaten Pohuwato diterima.

\section{e. Pengujian Hipotesis Kelima $\left(\mathbf{H}_{5}\right)$}

Pengaruh prosedur pemberian kredit berupa Condition of Economy $\left(\mathrm{X}_{5}\right)$ terhadap peningkatan jumlah nasabah pada Bank BRI Cabang Marisa Kabupaten Pohuwato dispesifikasikan dalam hipotesis kelima $\left(\mathrm{H}_{5}\right)$ yaitu:

H5: Prosedur pemberian kredit berupa Condition of Economy $\left(\mathrm{X}_{5}\right)$ berpengaruh positif dan siginifikan terhadap peningkatan jumlah nasabah pada Bank BRI Cabang Marisa Kabupaten Pohuwato.

Berdasarkan perhitungan analisis regresi berganda diperoleh nilai $t_{\text {hitung }}$ sebesar 3,241. Nilai ini lebih besar dari nilai $t_{\text {tabel }} 2,032$, yang berarti bahwa prosedur pemberian kredit berupa Condition of Economy $\left(\mathrm{X}_{5}\right)$ berpengaruh positif dan siginifikan terhadap peningkatan jumlah nasabah pada Bank BRI Cabang Marisa Kabupaten Pohuwato. hal ini juga didukung dengan nilai 
signifikansi sebesar 0,004 yang lebih kecil daripada tingkat kemaknaan 5\% $(0,004<0,05)$. Dengan demikian dapat dikatakan bahwa hipotesis penelitian yang menyatakan prosedur pemberian kredit berupa Condition of Economy $\left(\mathrm{X}_{5}\right)$ berpengaruh positif dan siginifikan terhadap peningkatan jumlah nasabah pada Bank BRI Cabang Marisa Kabupaten Pohuwato diterima.

\section{Uji Simultan (Uji-F)}

Uji-F atau Anovadigunakan untuk membandingkan tingkat signifikansi dengan (probabilityvalue) yang ditetapkan untuk penelitian ini dengan probability value hasil penelitian. Dalam penelitian ini digunakan 40 responden sebagai sampel, dimana df $1=6-1=5$, df $2=40-$ $5=35$ sedangkan $\alpha=5 \%=0.05$. Sehingga hasil regresi linear berganda dari Uji-F dapat dilihat pada Tabel. 10 berikut.

\section{Tabel. 10 Hasil regresi Uji-F}

ANOVA ${ }^{\mathrm{a}}$

\begin{tabular}{|c|c|c|c|c|c|c|}
\hline \multicolumn{2}{|c|}{ Model } & Sum of Squares & Df & Mean Square & F & Sig. \\
\hline & Regres & 2.940 & 5 & .588 & 11.137 & $.000^{\mathrm{b}}$ \\
\hline 1 & Residual & 1.162 & 35 & .053 & & \\
\hline & Total & 4.102 & 40 & & & \\
\hline
\end{tabular}

a. Dependent Variable: Y

b. Predictors: (Constant), $\mathrm{X}_{5}, \mathrm{X}_{3}, \mathrm{X}_{4}, \mathrm{X}_{1}, \mathrm{X}_{2}$

Sumber :Data olahan, 2017

Pengujian terhadap hipotesis keenam yaitu pengaruh variabel indepeden terhadap variabel dependen secara simultan menggunakan uji F.

$\mathrm{H}_{6}$ :Prosedur pemberian kredit berupa Character $\left(\mathrm{X}_{1}\right)$, Capacity $\left(\mathrm{X}_{2}\right)$, Capital $\left(\mathrm{X}_{3}\right)$, Collateral $\left(\mathrm{X}_{4}\right)$, dan Condition Of Economy $\left(\mathrm{X}_{5}\right)$ secara simultan berpengaruh positif dan signifikan terhadap peningkatan jumlah nasabah pada Bank BRI Cabang Marisa Kabupaten Pohuwato.

Berdasarkan perhitungan regresi linear berganda pada tabel di atas, nampak bahwa nilai $F_{\text {hitung }}$ lebih besar dari nilai $F_{\text {tabel }}(11,137>2,485)$ dengan probabilitas terjadinya kesalahan $F_{\text {hitung }}$ lebih kecil dari taraf kesalahan $(\alpha)$ yang ditetapkan yaitu $0,000<0,05$.

Hasil penelitian ini membuktikan bahwa variabel independen yaitu prosedur pemberian kredit berupa Character $\left(\mathrm{X}_{1}\right)$, Capacity $\left(\mathrm{X}_{2}\right)$, Capital $\left(\mathrm{X}_{3}\right)$, Collateral $\left(\mathrm{X}_{4}\right)$, dan Condition Of 
Pengaruh Prosedur Pemberian

Volume. 13, Nomor 2, Desember 2017

Halaman. 39-56

Kredit Terhadap Peningkatan

Jumlah Nasabah

Economy $\left(\mathrm{X}_{5}\right)$ secara simultan berpengaruh positif dan signifikan terhadap peningkatan jumlah nasabah (Y) pada Bank BRI Cabang Marisa Kabupaten Pohuwato.

\section{KESIMPULAN DAN SARAN}

\section{Kesimpulan}

Simpulan yang dapat ditarik pada penelitian ini adalah sebagai berikut:

1. Hipotesis penelitian yang menyatakan prosedur pemberian kredit berupa Character $\left(\mathrm{X}_{1}\right)$, Capacity $\left(\mathrm{X}_{2}\right)$, Capital $\left(\mathrm{X}_{3}\right)$, Collateral $\left(\mathrm{X}_{4}\right)$, dan Condition Of Economy $\left(\mathrm{X}_{5}\right)$ secara parsial berpengaruh positif dan signifikan terhadap peningkatan jumlah nasabah (Y) pada Bank BRI Cabang Marisa Kabupaten Pohuwato.

2. Hipotesis penelitian yang menyatakan Prosedur pemberian kredit berupa Character $\left(\mathrm{X}_{1}\right)$, Capacity $\left(\mathrm{X}_{2}\right)$, Capital $\left(\mathrm{X}_{3}\right)$, Collateral $\left(\mathrm{X}_{4}\right)$, dan Condition Of Economy $\left(\mathrm{X}_{5}\right)$ secara simultan berpengaruh positif dan signifikan terhadap peningkatan jumlah nasabah pada Bank BRI Cabang Marisa Kabupaten Pohuwato.

\section{Saran}

Saaran pada penelitian ini adalah sebagai berikut ;

1. Diharapkan kepada pihak BRI Cabang Marisa Kabupaten Pohuwato agar tetap melakukan pelayanan yang baik kepada calon nasabahnya sehingga calon nasabah baru dapat bertambah seiring dengan informasi dari nasabah lama.

2. Diharapkan kepada pihak praktisi khususnya pihak pemerintah tetap melakukan pengawasan secara kontinyu kepada semua pihak bank karena salah satu tugas pemerintah dalam dunia perbankan adalah memberikan kebijakan baik dalam menentukan bunga simpanan maupun bunga pinjaman bank karena tidak boleh melebihi batasan yang sudah ditetapkan oleh pemerintah.

\section{DAFTAR PUSTAKA}

Algifari. 2000. Analisis Regresi: Teori, Kasus, dan Solusi. BPFE: Yogyakarta. Dendawijaya,lukman,2003.Manajemen Perbankan Ghalia. Indonesia. Jakarta.

Komaruddin, 1994, Kamus Perbankan, Akuntansi Perbankan, Institut Bankir Indonesia. CV. Rajawali. Lapoliwa, N, 2000,. Jakarta. 
Fahmi Irham, 2013. Pengantar Mnajemen Keuangan Teori dan Soal Jawab, Cetakan Kedua, Alfabeta, Bandung.

Ghozali, Imam. 2005. Aplikasi Analisis Multivariate dengan Program SPSS. BP Universitas Diponegoro. Semarang.

Hasibun S.P. Malayu, 1996. Teori dan Praktek Kegiatan Operasional Bank. PT. Citra Haji Masagung, Cetakan Pertama, Jakarta.

Kasmir, 2002, Dasar-Dasar Perbankan, PT. Raja Grafindo Persada, Jakarta.

--------. 2003. Dasar-Dasar Perbankan. PT. Raja Grafindo Persada, Jakarta.

........, 2008. Bank dan Lembaga Keuangan Lainnya. PT Raja Grafindo Persada, Jakarta.

Martono, D Agus Marjito, 2012. Manajemen Keuangan, Edisi Kedua, Cetakan Kedua, Penerbit Ekonsia kampus Fakultas Ekonomi UII, Yokyakarta.

Rivai, Veithzal dan Andria Permata Veithzal. 2006. Credit Management Handbook(Teori, Konsep, Prosedur, dan Aplikasi Panduan Praktis Mahasiswa, Bankir, dan Nasabah), PT Raja Grafindo Persada, Jakarta.

Suyatno Thomas, dkk, 2007. Dasar-Dasar Perkreditan. Gramedia Pustaka Utama, Jakarta.

Sawaldjo, Puspopranoto. 2004. Keuangan Perbankan dan Pasar Keuangan (konsep, teori dan realita). Pustaka LP3ES Indonesia, Jakarta.

Saladin Djaslim, 1994, Dasar-dasar Manajemen Pemasaran Bank, CV Rajawali, Jakarta.

Triandaru Sigit dan Totok Budisantoso, 2008. Bank dan Lembaga Keuangan Lain. Salembaempat, Jakarta.

Undang-Undang No. 10 Tahun 1998 tentang Perbankan.

Undang-Undang Republik Indonesia Nomor 21 tahun 2008 tentang Perbankan Syariah.

Peraturan Bank Indonesia No. 11/ 26 /PBI/2009, http://id.shvoong.com/writing-andspeaking/presenting/2225846pengertian-dan-klasifikasi-nasabah

Pusat Informasi Pasar Uang (PIPU) Bank Indonesia. (Update 17 September 2017). 